Poznańskie Studia Teologiczne 30(2016), s. 433-448. doi: $10.14746 /$ pst.2016.30.21

Wojciech Medwid ${ }^{1}$

Instytut Teologiczny im. św. Jana Kantego w Bielsku-Białej

\title{
Obrona decyzji sumienia przez Tomasza More'a w obliczu uwięzienia i śmierci
}

W XVI wieku w Anglii król Henryk VIII rozpoczął proces unieważnienia swojego małżeństwa z Katarzyną Aragońską. Kanclerz Thomas Wolsey był zmuszony do rezygnacji z urzędu, ponieważ nie potrafił sprostać temu zadaniu. Na jego miejsce mianowano Tomasza More'a, człowieka religijnego i uduchowionego, ale i dobrze obeznanego z prawem kościelnym. Uważał on, że stwierdzenie nieważności małżeństwa leży w gestii jurysdykcji papieskiej. Papież Klemens VII zdecydowanie odrzucił propozycje króla. Wobec tego Henryk VIII, posługując się przekupstwem, poprosił o ekspertyzy kilku księży z najlepszych europejskich uniwersytetów. Wskutek tego parlament mianował go jedynym protektorem i najwyższą głową Kościoła angielskiego. Sprawę tę bez szczególnych trudności zaakceptował synod, ponieważ głosowanie odbyło się z klauzulą ograniczającą: „o ile pozwoli na to prawo Chrystusa”.

Tylko duchowni byli zobowiązani do złożenia przysięgi supremacji², w której deklarowali publicznie, że król jest głową Kościoła. Tomasz More, jako osoba świecka, nie był do tego zobligowany. Jednak, oddając królowi pieczęcie, zrzekł się urzędu kanclerza. Był to wyraz jego dezaprobaty wobec działań Henryka VIII. Jako człowiek głęboko religijny nie mógł sprzeciwić się głosowi sumienia. Oddał się życiu prywatnemu. Nie miał oszczędności, ponieważ przekazał je biednym, swojej rodzinie i rodzinom swoich bliskich. Niespodziewanie utracił wszystkie dochody z królewskiego dworu oraz znaczne wpływy. Odmówił także udziału w koronacji „,nowej” żony Henryka, Anny Boleyn, na królową Anglii. Nie był to akt zdrady, gdyż napisał do króla, że uznaje nową królową i życzy jej zdrowia i szczęścia. Mimo tego jego odmowa udziału w koronacji

\footnotetext{
${ }^{1}$ Wojciech Medwid, dr w zakresie historii dogmatu; ksiądz diecezji bielsko-żywieckiej Kościoła Rzymskokatolickiego; absolwent Wydziału Teologicznego Papieskiego Uniwersytetu Jana Pawła II w Krakowie; od 2012 r. wykładowca w Instytucie Teologicznym im. św. Jana Kantego w Bielsku-Białej. Obecnie pracuje w parafii św. Stanisława w Andrychowie.

${ }^{2}$ Por. The Act of Supremacy, 1534, w: Documents of the English Reformation, ed. G. Bray, Cambridge 2004, s. 113-114.
} 
została powszechnie zinterpretowana jako wyraz sprzeciwu. Początkowo uniknął oskarżenia o zdradę stanu, ale później w 1534 roku parlament uchwalił Akt sukcesji ${ }^{3}$ (dołączony kilka miesięcy później do Aktu supremacji), który zawierał przysięgę wymagającą uznania ewentualnych dzieci Henryka VIII i Anny Boleyn za prawowitych potomków oraz odrzucenia wszelkiej obcej zwierzchności, księcia czy monarchy. Także ona nie obowiązywała wszystkich obywateli, dotyczyła tylko piastujących urzędy państwowe i podejrzanych o zdradę. Dnia 13 kwietnia 1534 roku T. More został poproszony do stawienia się przed komisją i złożenia przysięgi, a kiedy odmówił, 17 kwietnia uwięziono go w Tower of London. Konsekwentnie milczał, co zgodnie z prawem uważane było za zgodę bez krzywoprzysięstwa ${ }^{4}$.

Od momentu aresztowania i uwięzienia w Tower (15 miesięcy) pisał listy do swoich krewnych, zwłaszcza do ukochanej córki Małgorzaty. Celem artykułu jest ukazanie niezwykłego męstwa broniącego decyzji swojego sumienia More'a, który nawet zagrożony uwięzieniem i śmiercią nie złożył przysięgi będącej aktem sprzeciwu wobec Boga. Podstawą refleksji jest korespondencja więzienna, a więc osobisty zapis doświadczeń. Składa się ona z 17 listów, których autorem był: T. More (ośmiu do córki M. Roper, dwóch do Mikołaja Wilsona, jednego do pana Leder i do przyjaciół), jego córka Małgorzata (dwa do ojca i jeden do Alicji Alington) i lady Alington (jeden do M. Roper). Wraz z Tomaszem aresztowano trzech kartuzów z klasztoru, w którym kiedyś spędził cztery lata, Richarda Reynoldsa z zakonu św. Brygidy i biskupa Rochester, Johna Fishera (kilka dni potem mianowanego przez papieża kardynałem). Przez niemal trzy tygodnie trzymano ich skutych łańcuchami. W czerwcu 1535 roku zostali osądzeni, skazani i straceni. W takiej sytuacji powstawały analizowane tutaj pisma więzienne. Należy zaznaczyć, że Tomasz More był odbierany przez jednych jako skrupulant, przez innych jako osoba zatwardziała w uporze, przez króla jako zdrajca, a przez rodzinę jako ktoś zagadkowy. Sumienie wzywało go do nieuznawania zwierzchnictwa króla nad Kościołem, a jego wierność Ewangelii i Kościołowi sprawiła, że opuścili go niemal wszyscy. Miał przeciwko sobie dostojników królewskich, episkopat i rodzinę. W jego listach można dostrzec kilka tematów i odniesień, do których często wracał przy uzasadnianiu swojej decyzji. Dotyczyło to takich kwestii, jak: złożenie przysięgi, pewność sumienia, upór, przekonania innych, ludzka słabość i lęk oraz wola Boża ${ }^{5}$.

${ }^{3}$ Por. The First Act of Succession (1534), w: Select Documents of English Constitutional History, ed. G. Adams, H. Stephens, New York 1914, s. 235-238.

${ }^{4}$ Por. J. Monti, The King's Good Servant But God's First, San Francisco 1997, s. 289-299; N. Harpsfield, The Life and Death of Sir Thomas More, London 1931, s. 12-30.

${ }^{5}$ Por. P. Ackroyd, The Life of Thomas More, New York 1999, s. 38-40. 


\section{Rzekome skrupuły a próby nakłonienia do zmiany decyzji}

Bliscy T. More'a wstawiali się za nim u wpływowych osób z dworu królewskiego. Przykładem mogą być starania Alicji Alington (córki z poprzedniego małżeństwa drugiej żony More’a). Celem było uzyskanie poparcia lorda kanclerza Tomasza Audleya, o czym dowiadujemy się z listu do Małgorzaty Roper. Lord obiecał, że okaże mu dobroć, ale jednocześnie zdumiewało go konsekwentne trwanie przy swoim zdaniu. Każdy uporał się z tą kwestią z wyjątkiem T. More'a i Johna Fishera. Stanowcza decyzja Tomasza została wyśmiana w bajkach, które opowiedział kanclerz. Pierwsza dotyczyła kraju zamieszkałego przez głupich, wśród których było kilku mądrych. Ci ostatni wiedzieli, że spadnie deszcz i zmieni w głupców wszystkich, których zmoczy. Dlatego zrobili sobie jaskinie i przeczekali do końca deszczu. Wyszli na zewnątrz i myśleli, że będą rządzić głupimi, ale głupi chcieli się rządzić sami. Kiedy mądrzy zobaczyli, że nie osiagną swojego celu, żałowali, że nie zmokli. Druga bajka była przestrogą przed skrupułami sumienia, jakich dopatrywał się w postawie More’a. Dotyczyła ona lwa, osła i wilka oraz ich spowiedzi. Spowiednik rozgrzeszył lwa z tego, że pożarł wszystkie zwierzęta, obok których przechodził. Usprawiedliwił go, dlatego że był on królem. Nie rozgrzeszył natomiast osła, który z głodu wyjął źdźbło słomy z buta swego pana, przez co - jak myślał - jego pan się przeziębił. Dlatego posłał go do biskupa. Z kolei wilkowi spowiednik zakazał jedzenia posiłków, których wartość przekraczała sześć pensów. Po kilku dniach, gdy wilk bardzo wygłodniał, zobaczył krowę i cielę. Sumienie podpowiedziało mu wówczas, że krowa warta jest tylko grosz, a cielę dwa pensy. Tak więc zjadł te zwierzęta. W związku z tym autor bajek konkludował, że decyzja More'a jest dla wielu osób zupełnie niezrozumiała ${ }^{6}$.

Na powyższy list i zawarte $\mathrm{w}$ nim zarzuty More odpowiedział obszernie wspólnie ze swoją córką w pisanej podczas widzenia korespondencji do A. Alington. Mimo że nadawcą listu była M. Roper, to jednak zawarty w nim przekaz był bliski duchowi i stylowi More’a. Wyjaśnił w nim swój sposób myślenia, bronił podjętej decyzji i tłumaczył mylne rozumienie osądu sumienia jako skrupułów. Warto zaznaczyć, że ów list potwierdza głęboką zażyłość między ojcem a córką.

Obie córki próbowały przekonać ojca, że jeśli będzie obstawał przy swoich poglądach, to opuszczą go wszyscy przyjaciele i nie będą w stanie niczego zrobić dla niego. Chciały, by jego sposób postępowania podobał się Bogu i jednocześnie zadowolił króla. Gdyby natomiast odmówił rzeczy, którą mógłby uczynić (nie obrażając Boga), sprowadziłby wielkie niebezpieczeństwo na swoją

\footnotetext{
${ }^{6}$ Por. Alice Alington to Margaret Roper, w: The Last Letters of Thomas More, ed. A. de Silva, Michigan 2001, s. 69-71; Lady Alington do Matgorzaty Roper (VI), w: T. More, Pisma więzienne, tłum. W. Giertych, Poznań 1985, s. 79-81; D. Sargent, Thomas More, Montana 2003, s. 248-254.
} 
duszę. Jednakże T. More tego rodzaju próby porównał do kuszenia w raju. Nie można na nim wymóc, aby w zamian za serdeczność przysięgał wbrew swemu sumieniu, bo w ten sposób skazywałby się na piekło. Wyjaśniając swoją postawę, odparł zarzuty skierowane przeciw niemu. Po pierwsze, jeśliby uczynił to, co podoba się królowi, i równocześnie nie obraziłby Boga, to z radością złożyłby przysięgę, ponieważ czuł się zobowiązany wobec króla z powodu jego szczodrości. Natomiast pozostając w zgodzie z własnym sumieniem, żadną miarą nie może tego uczynić. Po drugie, ma dokonać wyboru: albo śmiertelnie obrazić Boga, albo wytrzymać wszelkie doczesne cierpienia, które On dopuści. Był przekonany, że dobrze przemyślał sprawę i wziął pod uwagę to, co w najgorszym wypadku może spaść na niego. Mimo własnej słabości i bojaźni serca ufał Bogu, który da mu siłę do przetrwania. W tej kwestii miał wzgląd tylko na Boga. Nie obchodzili go ludzie, którzy myśleli inaczej i mówili, że to nie sprawa sumienia, ale głupie skrupuły. Nie brał pod uwagę opinii dostojników niepodzielających jego opinii. Poza tym nie ingerował w sumienie osób, które złożyły przysięgę, ani nie zamierzał być ich sędzią. Po trzecie, nie zlekceważył tego zagadnienia, bo przez wiele lat studiów i wnikliwych dociekań wgłębiał się w nie i nie znalazł argumentu, który nakłoniłby go do zmiany sposobu myślenia. Wobec tego nie miał powodów do obaw?

Tomasz More stwierdził, że nie obchodzą go bajki, w których T. Audley kpi z jego sumienia. Trzeba zaznaczyć, że broniąc swego stanowiska z lekkim poczuciem humoru, umiejętnie wyszedł $\mathrm{z}$ opresji. Jeśli chodzi o bajkę o deszczu, zaznaczył, że nie umie osądzić, kogo kanclerz uważa za głupiego, a kogo za mądrego. Oznajmił, że sam zalicza się do głupców, bo takie znaczenie ma jego nazwisko w języku greckim, oraz że nie pragnie władzy, bo miał ją w królestwie i sam z niej dobrowolnie zrezygnował, a poświadczyć to mogą Bóg i jego sumienie. Pozostała mu więc tylko modlitwa o mądrość, aby nie utracić nieba jak nieroztropne panny z Ewangelii, którym zabrakło światła w lampie. Podobne wątpliwości miał w przypadku bajki o lwie i wilku. Postawione przez niego pytania miały pobudzić do myślenia i wyciąnnięcia wniosków. $Z$ jednej strony, kim jest ten, kto dobrowolnie rozszerzył swoje sumienie? A z drugiej, kogo obrazuje dobry, dyskretny spowiednik z bajki? Tomasza More'a nie dziwi, że utożsamia się go z głupim i skrupulatnym osłem ${ }^{8}$.

Zasmuciły go natarczywość oraz wielki trud córki nakłaniającej go do złożenia przysięgi. Dał do zrozumienia, że miał pewność, podejmując decyzję, oraz

${ }^{7}$ Por. Margaret Roper to Alice Alington, w: The Last Letters of Thomas More, dz. cyt., s. $72-$ -73; Matgorzata Roper do Alicji Alington (VII), w: T. More, Pisma więzienne, dz. cyt., s. 82-84; G. Wegemer, Thomas More: A Portrait of Courage, New York 1997, s. 198-207.

${ }^{8}$ Por. Margaret Roper to Alice Alington, w: The Last Letters of Thomas More, dz. cyt., s. 74-77; Matgorzata Roper do Alicji Alington (VII), w: T. More, Pisma więzienne, dz. cyt., s. 85-88; J. Monti, The King's Good Servant But God's First, dz. cyt., s. 409-415; G. Logan, The Cambridge Companion to Thomas More, Cambridge 2011, s. 225-226. 
już wcześniej dał jednoznaczną odpowiedź. Natomiast tego, co poruszyło jego sumienie, nie odkryje przed żadnym człowiekiem .

\section{Pewność ukształtowanego sumienia $\mathrm{w}$ trosce o wieczność}

Priorytetową kwestią stała się dla Tomasza pewność dobrze ukształtowanego sumienia. Jego osąd winien zagwarantować mu zbawienie. Zmiana zdania wywołana strachem nie byłaby dobra dla jego duszy. Gdyby miał się załamać i upaść, składając przysięgę, wolałby wcześniej ponieść karę za odmowę, aby mieć większą nadzieję na łaskę ponownego powstania. Przyczyny swojej postawy mógłby zdradzić wyłącznie na rozkaz króla. Jego zdaniem, ci, którzy ostatecznie spełnili rozkaz władcy, postapili wbrew wyrażanym wcześniej poglądom, a monarcha nie przedstawił żadnych nowych okoliczności, które mogłyby skłonić go do zmiany zdania. Przykład innych ludzi obawiających się utraty posiadłości ziemskich nie mobilizuje go do zmiany poglądów ani postępowania. Swoją pewność i zgodność słów z czynami potwierdza, mówiąc, że jego sumienie nakazuje mu odmowę. Nie jest głupcem i bez przyczyny nie ryzykowałby utraty majętności, ziemi i życia, ale woli to stracić, niż złamać Boże zasady. Bez wątpienia wielu uczonych podziela niektóre z jego zastrzeżeń. Są też i tacy, którzy, składając przysięgę, postapili wbrew sobie. Z kolei ci, którzy są w niebie, o pewnych sprawach myśleli tak, jak on, o czym można się dowiedzieć z ich pism ${ }^{10}$.

Trzeba zaznaczyć, że Tomasz działał w dobrej wierze, a gdyby postapił inaczej, wystawiłby swoją duszę na niebezpieczeństwo wiecznego potępienia. Wewnętrzny głos podpowiedział mu, że nie byłoby godziwe złożenie przysięgi, i to jest jeden $\mathrm{z}$ tych przypadków, w których człowiek nie jest zobowiązany do spełnienia królewskiego polecenia. Nie jest również zobowiązany do zmiany swojego sumienia i dostosowywania go do opinii jednego królestwa, które stoi w opozycji do stanowiska całego chrześcijańskiego świata. Jednym z motywów jego postępowania jest chęć zachowania całkowitej zgody z własnymi przekonaniami $^{11}$.

Trzeba zaznaczyć, że w postawie T. More'a dostrzegalna jest nieustanna troska o własną duszę i zbawienie, która przewyższa obawę przed tym, co może go spotkać za niewywiązanie się z królewskiego polecenia. Był przekonany, że złożenie przysięgi jest czymś niezrozumiałym, nierozsądnym i że jest wielkim nie-

\footnotetext{
${ }^{9}$ Por. To Margaret Roper, w: The Last Letters of Thomas More, dz. cyt., s. 65; Do Matgorzaty Roper (III), w: T. More, Pisma więzienne, dz. cyt., s. 76.

${ }^{10}$ Por. Margaret Roper to Alice Alington, w: The Last Letters of Thomas More, dz. cyt., s. 84-86; Matgorzata Roper do Alicji Alington (VII), w: T. More, Pisma więzienne, dz. cyt., s. 94-96.

${ }^{11}$ Por. To Margaret Roper, w: The Last Letters of Thomas More, dz. cyt., s. 57, 60; Do Matgorzaty Roper (I), w: T. More, Pisma więzienne, dz. cyt., s. 70. 72-73; J. Monti, The King's Good Servant But God's First, dz. cyt., s. 406-408.
} 
bezpieczeństwem dla duszy, choć inni traktują to jako drobnostkę. $Z$ tego względu jego sumienie było oceniane jako skrupulatne. Tomasz More był pewny, że Bóg go umocni. Zaznaczył też, że nie uchylałby się od złożenia przysięgi, gdyby taki był osąd jego sumienia, choćby inni odmówili. Godne uwagi jest jego odniesienie do innych osób. Stanowczo podkreślił, że nie ma zamiaru powierzać własnej duszy innemu człowiekowi, bo nikogo nie jest pewny. Dla osiagnięcia jakichś korzyści bądź powodowani strachem mogliby poprowadzić jego duszę złą drogą. Przekonał się, że ludzka przyjaźń jest niestała. Lepiej samemu odpowiadać za własną duszę, niż mieć wzgląd na innych. Poza tym w tej sprawie nie zamierza brać przykładu z mądrych ludzi. Zastanawiał się nad tym, czy dobrze postąpili ci, którzy złożyli przysięgę, i czy sumienie niczego im nie wyrzuca. Czy mimo przeciwnego osądu sumienia powinien dla towarzystwa pójść ich drogą? Gdyby tak postąpił, Najwyższy Sędzia skazałby go na piekło, ponieważ jego wybór byłby niezgodny z wewnętrznym przekonaniem. Jeśli jest między nimi jakakolwiek więź, inni ludzie powinni go naśladować ${ }^{12}$.

Motywując swój wybór, T. More wyjaśnił, jaki jest stosunek osądu sumienia do prawa. Potwierdził, że z jednej strony każdy człowiek ma obowiązek bezwzględnie zachowywać prawo pod karą doczesną lub karą gniewu Bożego, ale z drugiej strony nikt nie ma obowiązku przysięgać, że każde prawo jest słuszne. Dlatego człowiek nie musi się stosować do tych punktów, które są bezprawiem. Jeśli parlament ustanowił prawo, żeby go skrzywdzić, to jest ono niesprawiedliwe. Jego zdaniem, nawet po wprowadzeniu niesłusznego prawa nie może być ono uchwalone przez sobór. Podkreślił, że człowiek ma prawo do wyboru zgodnego z własnymi przekonaniami, wobec czego nie może przysięgać wbrew swojemu sumieniu, a jego osądu nie może zmieniać ludzkie prawo niezgodne z ustaleniami soboru powszechnego. Jedynie orzeczenia soboru bądź specjalne objawienie i wyraźny rozkaz Boga mogą być powodem do zmiany własnej opinii i orientacji sumienia. Sumienie rozstrzygające przeciw oczywistej prawdzie jest godne potępienia ${ }^{13}$.

\section{Sumienie innych a wlaściwe rozeznanie królewskiej sprawy}

W odpowiedziach na zarzuty T. More poruszył temat sumienia innych oraz kwestię rozeznania słynnej królewskiej sprawy. Określił stanowczo, że nie zamierza nikogo winić ani krytykować autorów ustaw i tych, którzy złożyli przysięgę,

${ }^{12}$ Por. Margaret Roper to Alice Alington, w: The Last Letters of Thomas More, dz. cyt., s. 78-80; Małgorzata Roper do Alicji Alington (VII), w: T. More, Pisma więzienne, dz. cyt., s. 89-90.

${ }^{13}$ Por. Margaret Roper to Alice Alington, w: The Last Letters of Thomas More, dz. cyt., s. 81-83; Matgorzata Roper do Alicji Alington (VII), w: T. More, Pisma więzienne, dz. cyt., s. 91-93; B. Cummings, Conscience and the law in Thomas More, „Renaissance Studies”, vol. 23(2009), s. $463-471$. 
ponieważ niestosowne byłoby potępianie czyjekolwiek sumienia. Ponadto nikogo nigdy nie odwodził od przysięgi ani nikomu nie radził, by jej odmówił, ani też nie był przyczyną czyichś skrupułów. Uważał, że każdy człowiek winien postąić zgodnie z własnym sumieniem. Byłoby dobrą rzecza, gdyby i jemu na to pozwolono ${ }^{14}$. Należy podkreślić, że T. More był lojalny i wierny wobec króla Henryka VIII nawet w więzieniu, a pobyt w nim odbierał jako okazję do duchowego wzrostu. Nieustannie miał nadzieję, że Bóg nie dopuści, aby tak dobry i mądry władca w zły sposób odpłacił mu długą służbę. Widział dwa wyjścia z tej sytuacji: albo Bóg sprawi, że król zachowa swoją życzliwość wobec More’a, albo udzieli mu dość siły, aby cierpliwie zniósł karę, a przez to zmniejszył kary czyśćcowe i powiększył nagrodę w niebie ${ }^{15}$.

W pierwszym liście do Mikołaja Wilsona (spowiednika i kapelana króla) więzionego również w Tower of London, wyraźnie stwierdził, że nigdy nie używał żadnych sposobów, aby obudzić u innych skrupuły związane z przysięgą jak również nigdy nie doradzał nikomu czegoś przeciwnego. Ponadto nie ma zamiaru poznawać opinii innych osób, bo nie chce być odpowiedzialny za nikogo i pozostawia każdego jego własnemu sumieniu. Natomiast z łaską Bożą pragnie podazżać za swoim. Poza tym nie miesza się do niczyich spraw, zajmuje się wyłącznie własnymi. Bez wątpienia - wskazał More - przysięga przeciw własnemu sumieniu ściaga na człowieka niebezpieczeństwo potępienia ${ }^{16}$.

W drugim liście do M. Wilsona solidaryzował się z nim w jego niełatwym położeniu. Smutek królewskiego spowiednika był skutkiem uwięzienia, straty dóbr, dochodów i pociechy przyjaciół, ale też niepokoju i udręki duszy z powodu wątpliwości sumienia. Tomasz odniósł się do słynnej sprawy króla, podkreślając, że wiele razy oboje rozmawiali na ten temat i zgadzali się w każdym punkcie. Sporo czasu poświęcili także na wspólne studiowanie tekstów świętych autorów i Biblii, ponieważ otrzymali polecenie, aby bezstronnie rozważyć wszystko, co o tej sprawie mówi Pismo i doktorzy. On sam wymieniał się opiniami z innymi osobami znającymi ów problem. W tym wszystkim starał się jak najlepiej zrozumieć oba punkty widzenia i obiektywnie rozważyć, ku czemu skłoni się jego sumienie. Tak więc podtrzymuje opinię będącą wynikiem wnikliwych studiów nad zagadnieniem. Trzeba podkreślić, że More wskazał podstawy powziętej przez siebie decyzji. Gdy rozpoczynał służbę na dworze królewskim, otrzymał polecenie respektowania przede wszystkim praw Bożych, a dopiero potem królewskich. Widząc, co dzieje się po przedstawieniu królowi opinii, nie

\footnotetext{
${ }^{14}$ Por. To Margaret Roper, w: The Last Letters of Thomas More, dz. cyt., s. 57-58. 60-61; Do Matgorzaty Roper (I), w: T. More, Pisma więzienne, dz. cyt., s. 69-70. 73-74.

${ }^{15}$ Por. Margaret Roper to Alice Alington, w: The Last Letters of Thomas More, dz. cyt., s. 88; Matgorzata Roper do Alicji Alington (VII), w: T. More, Pisma więzienne, dz. cyt., s. 98.

${ }^{16}$ Por. To Dr Nicholas Wilson, w: The Last Letters of Thomas More, dz. cyt., s. 90; Do Mikołaja Wilsona (VIII), w: T. More, Pisma więzienne, dz. cyt., s. 100.
} 
chciał wpływać na jego upodobania i zdecydował, że przestanie zajmować się powtórnym ożenkiem monarchy. Poza tym wskazał sprawy, które trzeba było rozważyć na podstawie Pisma Świętego i jego komentatorów, jak np. błędy znalezione w bulli o dyspensie, które powstały z powodu nieprawdziwych sugestii i niedostatecznego ich uzasadnienia. Nie chciał również podejmować się określania i rozstrzygania, jaka jest natura tego, co zawiera przysięga. Przyczyny, dla których odmówił przysięgi, pozostaną na zawsze tajemnicą jego sumienia. Jeśliby je wyjawił, to - jego zdaniem - niektórzy ludzie byliby zaskoczeni. Do końca pozostał tajemniczy i trwał przy swoich racjach, o których słuszności i prawdziwości był przekonany ${ }^{17}$.

\section{Odmowa przysięgi to zwykły upór?}

Stanowcza i zdecydowana postawa T. More'a (przez wielu odbierana jako upór) spowodowała u jego najbliższych, szczególnie u ukochanej córki Małgorzaty akceptację sytuacji, w której się znalazł i pogodzenie się z możliwością ostatecznego rozstania spowodowanego śmiercią. Warto podkreślić, że córka postrzegała More'a jako wielkiego i świętego człowieka będącego największą pociechą jej życia. W ostatnim liście do ojca wskazała na jego miłość i pobożność, ale przede wszystkim na przejrzystą jasność duszy, które ujawniły się w takim panowaniu nad sobą, że potrafił on bez sprzeciwu przyjąć dożywotnie uwięzienie i nie dać się nakłonić do woli innych. Wydarzenie to nie zaskoczyło go, ponieważ był przygotowany na taką ewentualność. Niewzruszony przykład ojca oddziaływał na postawę Małgorzaty, która obiecała żyć przykładnie ${ }^{18}$. Jak bardzo córka ceniła Tomasza, można wywnioskować z jej listu z maja 1534 roku, gdzie wskazała na jego cechy. Napisała, że jego serce odznacza się prawością, wzniosłościa, wolnością od wszelkiej brudnej miłości światowych spraw oraz jest ściśle związane z miłością Boga i pragnieniem nieba. Jej ojciec jest także prawdziwym czcicielem i wiernym sługą Boga ozdobionym szlachetną szatą niebiańskich cnót, a przebywanie w jego obecności zawsze jest budujące ${ }^{19}$. Natomiast przypisywanie mu uporu i zawziętości z powodu niechęci do wyjawienia powodów odmowy tłumaczył tym, że obawiał się reakcji króla na jego decyzję. Wyjaś-

\footnotetext{
${ }^{17}$ Por. To Dr Nicholas Wilson, w: The Last Letters of Thomas More, dz. cyt., s. 91-96; Do Mikołaja Wilsona (IX), w: T. More, Pisma więzienne, dz. cyt., s. 100-106; B. Cummings, Conscience and the law in Thomas More, „Renaissance Studies”, vol. 23(2009), s. 476-479.

${ }^{18}$ Por. From Margaret Roper, w: The Last Letters of Thomas More, dz. cyt., s. 97-98; Matgorzata Roper do Tomasza More (X), w: T. More, Pisma więzienne, dz. cyt., s. 106-108; J. Monti, The King's Good Servant But God's First, dz. cyt., s. 445-447.

${ }^{19}$ Por. From Margaret Roper, w: The Last Letters of Thomas More, dz. cyt., s. 66-67; Matgorzata Roper do Tomasza More (IV), w: T. More, Pisma więzienne, dz. cyt., s. 77-78.
} 
nienie przyczyn rozdrażniłoby monarchę jeszcze bardziej i dlatego zniesie grożące mu niebezpieczeństwo ${ }^{20}$.

Należy zaznaczyć, że w czasie uwięzienia T. More jeszcze bardziej utwierdził się w przekonaniu co do słuszności podjętej przez siebie decyzji. W kolejnym liście do córki potwierdził, że będzie postępował godziwie, choćby ludzie to oceniali inaczej, bo świat - przez błąd rozumowania bądź fałszywe świadectwa - uznaje czasem zło za prawość. Dopominał się więc prawa do zachowania spokoju sumienia niezależnie od tego, jak jest postrzegana jego postawa. Wyjaśnił, że zgodnie z obowiązującym prawem odmowa przysięgi to przestępstwo, natomiast bojaźń Bożą ocenia się jako upór, tymczasem on daleki był od wszelkiej nieustępliwości, która go wywołuje. Wolał znieść wszystkie cierpienia i niebezpieczeństwa wynikające z przekroczenia prawa niż przez wyjaśnienie przyczyn dać powód do rozdrażnienia Henryka VIII. Aby nie uważano go za nieustępliwego i zawziętego, zgodzi się na podanie warunków, w których sumienie pozwoliłoby mu złożyć przysięgę, ale dopiero po uzyskaniu pozwolenia i nakazu króla. Uchroniłoby to więc go przed gniewem lub karą. Obiecał, że jeśli po odkryciu przyczyn swojej decyzji i wyjaśnieniu ich treść przysięgi zostanie tak zmodyfikowana, że będzie mógł ją złożyć zgodnie z własnym sumieniem, to na pewno to uczyni. Podkreślił też, że niezależnie od motywów, które kierują jego postępowaniem, uważa się je za przejaw wielkiego uporu, ponieważ wielu mądrzejszych ludzi postąpiło, jak zażądał król. Nawet gdyby ustanowiono prawo, na skutek którego poniósłby śmierć, to przed Bogiem i tak będzie niewinny ${ }^{21}$.

Także w liście do pana Leder Tomasz More wspomina o przyczynach swojej decyzji. Gdyby kierował się uporem, to nie pozwoliłby sobie na zwyczajne wyznanie prawdy, ponieważ bałby się nagany lub wstydu. Nie ma zamiaru liczyć się z uznaniem świata, gdyż to, co robi, wynika nie z uporu, ale z troski o zbawienie duszy. Jego zachowanie odbierane jest jako upór i zawiść, bo będąc $\mathrm{w}$ więzieniu, do tej pory nie prosił króla o ułaskawienie. Tłumaczył to skromnością i głębokim szacunkiem, bo cokolwiek by napisał, wzbudziłby większą niechęć do swojej osoby. Z kolei - zdaniem króla - cechował go zawzięty upór. Zaznaczył, że gdyby kiedykolwiek złożył przysięgę, będzie to wymuszone więzieniem i brutalnym traktowaniem. Można zauważyć, że nie był do końca pewny siebie, ponieważ przewidywał, że może się złamać, ale mając na uwadze Boże wsparcie, liczył na to, że zdoła ponieść konsekwencje swojego wyboru ${ }^{22}$.

\footnotetext{
${ }^{20}$ Por. To Margaret Roper, w: The Last Letters of Thomas More, dz. cyt., s. 61; Do Matgorzaty Roper (I), w: T. More, Pisma więzienne, dz. cyt., s. 71.

${ }^{21}$ Por. To Margaret Roper, w: The Last Letters of Thomas More, dz. cyt., s. 99-101; Do Matgorzaty Roper (XI), w: T. More, Pisma więzienne, dz. cyt., s. 108-111; B. Cummings, Conscience and the law in Thomas More, „Renaissance Studies”, vol. 23(2009), s. 480-485.

${ }^{22}$ Por. To Master Leder, w: The Last Letters of Thomas More, dz. cyt., s. 110-111; Do Pana Leder (XIII), w: T. More, Pisma więzienne, dz. cyt., s. 117-118.
} 
Zdecydowana postawa More'a bez wątpienia mogła być odczytywana jako upór, tym bardziej że po roku pobytu w więzieniu na polecenie Henryka VIII pokazano mu nowe ustawy uchwalone przez parlament, żądając jego opinii na temat zapisu, że każdy król i każdy jego następca to najwyższy na Ziemi zwierzchnik Chrystusowego Kościoła w Anglii. More przypominał, że nieraz jasno wypowiadał zgodne z prawdą zdanie na ten temat. Natomiast obecnie nie chce już dyskutować o uprawnieniach króla ani papieża, jest za to wiernym poddanym króla i codziennie modli się za niego. Postanowił również nie badać żadnych spraw tego świata ani się $w$ nie nie wtrącać. Jedynym przedmiotem jego uwagi jest teraz męka Chrystusa i Jego odejście z tego świata. Nie chce wpływać na opinie innych ludzi ani oceniać ich poglądów. Trzeba też zaznaczyć, że pomimo odmiennego zdania swoich bliskich T. More cały czas życzliwie wypowiadał się o nich ${ }^{23}$.

Henryk VIII wyraził wielkie niezadowolenie z powodu odpowiedzi Tomasza. Stwierdził, że motywowane uporem i złośliwością postępowanie wywarło zły i szkodliwy wpływ na mieszkańców królestwa. More martwił się opinią króla, ale nie poczuwał się do złośliwości. Tłumaczył, że jego sytuacja i tym samym pewność sumienia to efekt słuchania czystego wewnętrznego głosu, a jego dusza nie dozna szkody, nawet jeśli on zostanie pozbawiony głowy. Od zawsze miał niezłomny zwyczaj najpierw słuchać Boga, a potem króla. W przypadku gdyby jego sumienie podpowiadało, że ustawa jest zła, a on w związku z tym niczego by nie robił, to powinien zostać zmuszony do zajęcia stanowiska, które prowadziłoby albo do zguby duszy, albo do zagłady ciała. Stanowczo odmawiając złożenia przysięgi, potwierdził, że jest całkowicie pewny, iż jego sumienie od dłuższego czasu jest oświecone w wystarczającym stopniu, aby zapewnić mu zbawienie. Tak więc dla More'a Boże wartości i prawo były najważniejsze i niepodważalne, nawet jeśli ich obrona kosztowałaby go utratę życia ${ }^{24}$.

\section{Między ludzką słabością i przyjaźnią a Bożym wsparciem}

Mając na względzie sprawy duchowe T. More'a, trzeba wspomnieć o jego świadomości własnej słabości, ale i stosunku do coraz bardziej realnej śmierci. Przygotowując się na najgorsze, obawiał się bólu i śmierci. Wszystko to przeżywał w zupełnej samotności. Najpierw martwiła go śmierć, ale z czasem uznał ją

${ }^{23}$ Por. To Margaret Roper, w: The Last Letters of Thomas More, dz. cyt., s. 112-115; Do Matgorzaty Roper (XIV), w: T. More, Pisma więzienne, dz. cyt., s. 119-122; J. Wood, Sir Thomas More: A Man for One Season, w: The Broken Estate: Essays on Literature and Belief, New York 2000, s. 24-27.

${ }^{24}$ Por. To Margaret Roper, w: The Last Letters of Thomas More, dz. cyt., s. 118-122; Do Małgorzaty Roper (XV), w: T. More, Pisma więzienne, dz. cyt., s. 122-127; D. Sargent, Thomas More, Montana 2003, s. 265-271. 
za błahostkę. Sumienie podpowiedziało mu, że ocalenie ciała oznaczałoby zgubę duszy, zaś niesprawiedliwy wyrok śmierci za dobre postępowanie jest przypadkiem, w którym człowiek może stracić życie, nie ponosząc szkody na duszy. Okoliczność tę postrzegał jako bezcenne dobro z ręki Boga. Z jednej strony znał swą słabość i nie był tak szalony, żeby ręczyć za siebie, że wytrwa, a z drugiej nigdy nie prosił Boga, aby go wyswobodził z tej sytuacji czy zachował od śmierci. Poddał wszystko wyłącznej woli Boga, który lepiej widzi niż on i wie, co jest dla niego najlepsze ${ }^{25}$.

Sytuacja, w której znalazł się More, nie zmieniła jego nastawienia do Boga i do życia. Warto zaznaczyć, że w jego postawie można dostrzec zarówno będący darem Boga wielki pokój serca, jak i prawość. Prosił Boga o umocnienie w prawdzie, wierności i niezłomności. Nie spodziewał się również długiego życia ani za nim nie tęsknił. Deklarował natomiast, że będzie szczęśliwy, gdy Bóg powoła go $\mathrm{z}$ tego świata. Najwięcej radości czerpał z tego, że nie życzy nikomu $\mathrm{zła}^{26}$.

Należy podkreślić, że nieobce mu było uczucie lęku. Z każdym dniem dzięki Bożej pomocy - pod wpływem obawy przed piekłem, nadziei nieba i pamięci o męce Chrystusa - zmniejszał się jego strach przed śmiercią. Bardziej lękał się Bożego gniewu niż gniewu królewskiego. Prosił Boga, aby szlachetne serce króla napełnił życzliwością wobec niego i jego bliskich, ponieważ był wierny Henrykowi VIII i codziennie modlił się za niego. Twierdził, że gniew monarchy skończyłby się, gdyby poznał jego duszę. Chciał, żeby Bóg wprowadził go do szczęścia w niebie, jednocześnie prosił o łaskę wytrwałości we wszystkich udrękach i zmartwieniach ${ }^{27}$. Z kolei w listach do swoich przyjaciół wyrażał niepewność i powierzał się ich dobroci. Nie wiedział, czego będzie potrzebował w więzieniu. Prosił także, żeby prośby przekazywane przez jego córkę, Małgorzatę, potraktowali jako jego własne ${ }^{28}$.

Trzeba zaznaczyć, że świadomość własnej ograniczoności, słabości i lęku skłoniła go do wzorowania się na postawie św. Piotra. Gdyby opanował go wielki lęk, to wzorując się na Piotrze tonącym na burzliwym morzu, będzie prosił Chrystusa o pomoc. Jeśli natomiast złoży przysięgę i wyprze się w ten sposób wiary, to ma nadzieję, że Bóg okaże mu dobroć i litość, pomoże mu powstać

${ }^{25}$ Por. To Margaret Roper, w: The Last Letters of Thomas More, dz. cyt., s. 102-103; Do Małgorzaty Roper (XI), w: T. More, Pisma więzienne, dz. cyt., s. 112-113.

${ }^{26}$ Por. To Margaret Roper, w: The Last Letters of Thomas More, dz. cyt., s. 62-63; Do Matgorzaty Roper (II), w: T. More, Pisma więzienne, dz. cyt., s. 74-75; S. Smith, Interrogating Thomas More: The Conundrums of Conscience, "University of St. Thomas Law Journal" 1(2003), s. 592$-596$.

${ }^{27}$ Por. To Margaret Roper, w: The Last Letters of Thomas More, dz. cyt., s. 64-65; Do Matgorzaty Roper (III), w: T. More, Pisma więzienne, dz. cyt., s. 75-77.

${ }^{28}$ Por. To All His Friends, w: The Last Letters of Thomas More, dz. cyt., s. 68; Do przyjaciót (V), w: T. More, Pisma więzienne, dz. cyt., s. 74-75; R. Marius, Thomas More, Harvard 1999, s. 497-501. 
i ponownie wyznać prawdę sumienia. Tomasz wierzył w to, że Chrystus nie pozwoli mu zginąć, jeżeli będzie niewinny, a jeśli się tak zdarzy, to jego śmierć ukaże chwałę Bożej sprawiedliwości. Poddał się woli Bożej, ponieważ nawet to, co człowiekowi wydaje się złe, Bóg może wykorzystać dla jego dobra ${ }^{29}$.

Warto zauważyć, że w ostatnim etapie życia pod wpływem samotności, uwięzienia oraz wizji możliwej śmierci Tomasz More jeszcze bardziej przylgnął do Boga oraz nabrał dystansu do siebie i doczesności, a jednocześnie utwierdził się w swoim wewnętrznym przekonaniu. Kolejny list do córki był tego wyraźnym potwierdzeniem. Według More’a należy mocno trwać w miłości do Boga i całkowicie uzależnić się od Jego nadziei i mocy. Ponadto niewiele powinno się troszczyć o nędzny świat. Dzięki temu można uniknąć grzechu i zdobyć cnotę. Mimo że czuł się biedny i nieszczę́liwy, wierzył, że Bóg go umocni i okaże mu wielkie miłosierdzie, jeśli będzie o to prosił. More przewidywał wszystkie niebezpieczeństwa i rodzaje śmierci, jakie mogły go spotkać. Skutkiem tego były bezsenność i niepokój. Ponadto nigdy nie zamierzał dopuścić się niegodziwości, która naraziłaby go na Boży gniew, nawet choćby to oznaczało przyjęcie największych cierpień. Podkreślił, że człowiek, który dostrzega niebezpieczeństwo, powinien dokładnie ukształtować sumienie, korzystając z nauki i dobrych rad, aby nabrać pewności, że może ono stanowić o zbawieniu. W przeciwnym wypadku trzeba je zreformować ${ }^{30}$.

W liście do starego i drogiego przyjaciela, Antoniego Bonvisiego, kupca z Lukki, T. More wypowiedział się na temat wartości przyjaźni w trudnych chwilach. Mimo braku szczęścia pocieszała go świadomość, że ma najwspanialszego i najbardziej godnego jego miłości przyjaciela. Tomasz czuł się odrzucony, upodlony i dotknięty nieszczęściem, jednakże wierna i stała przyjaźń wynagradzała mu wszelkie trudności i była wspaniałomyślnym darem szczególnej łaski ${ }^{31}$. W ostatnim najbardziej wzruszającym liście do córki napisanym w przeddzień stracenia serdecznie wspomniał wszystkich członków swej rodziny oraz służących i pożegnał się z tymi, którzy byli mu drodzy ${ }^{32}$.

${ }^{29}$ Por. Margaret Roper to Alice Alington, w: The Last Letters of Thomas More, dz. cyt., s. 87-89; Matgorzata Roper do Alicji Alington (VII), w: T. More, Pisma więzienne, dz. cyt., s. 97-99.

${ }^{30}$ Por. To Margaret Roper, w: The Last Letters of Thomas More, dz. cyt., s. 104-107; Do Małgorzaty Roper (XII), w: T. More, Pisma więzienne, dz. cyt., s. 113-117; R. Marius, Thomas More, Harvard 1999, s. 508-512.

${ }^{31}$ Por. To Antonio Bonvisi, w: The Last Letters of Thomas More, Michigan 2001, s. 123-126; Do Antoniego Bonvisi (XVI), w: T. More, Pisma więzienne, dz. cyt., s. 127-129.

${ }^{32}$ Por. To Margaret Roper, w: The Last Letters of Thomas More, dz. cyt., s. 127-130; Do Matgorzaty Roper (XVII), w: T. More, Pisma więzienne, dz. cyt., s. 130-131; N. Harpsfield, The Life and Death of Sir Thomas More, London 1931, s. 68-70. 


\section{Podsumowanie}

Tomasz More przygotowywał się do męczeństwa przez 15 miesięcy pobytu w Tower of London. Znając porywczy charakter Henryka VIII, wiedział, że czeka go śmierć. Został osądzony, skazany i ścięty na Tower Hill 6 lipca 1535 roku. Analiza korespondencji więziennej More'a umożliwiła wyeksponowanie jego niezłomnej obrony decyzji sumienia. $Z$ jego wyjątkowej reakcji na ustawę o supremacji królewskiej można wyciagnąć kilka wniosków dotyczących zarówno sposobu jego myślenia, jak i motywów, jakimi się kierował.

Po pierwsze, pozostał wierny sumieniu, chociaż do zmiany zdania namawiała go żona, a przede wszystkim jego ukochana córka Małgorzata. W jej troskliwym uporze dostrzegał niezachwianą miłość. Jednak nawet osoba tak mu bliska nie była w stanie skusić go do grzechu. Bardzo go to przygnębiało, ale nie złamało jego woli. Nawet uwięzienie i realna groźba śmierci nie podała w wątpliwość jego stanowczego przekonania. Nieraz wspominał w listach, że długo studiował, medytował i modlił się do momentu nabycia niezbitego przekonania, iż składając wymagany podpis, wyprze się wiary i utraci przez to wieczne zbawienie. Jednakże uwięziony milczał, nie złożył przysięgi i niczego nie wyjaśnił. Takie zachowanie postrzegane było przez wielu jako upór i złośliwość. Nie poruszyły go oskarżenia, pomówienia, groźby i pochlebstwa. Nie można było znaleźć prawnych podstaw do skazania go na śmierć. Natomiast dzięki swoim umiejętnościom adwokackim regularnie i skutecznie obalał prawną wartość wnoszonych przeciw niemu oskarżeń o bunt i upór. Uznał, że sprzeciwiłby się Bogu, gdyby uległ, jak to uczyniło wiele zalęknionych o swoją głowę znaczących osób na dworze królewskim.

Po drugie, w jego listach więziennych nie ma żadnego złego słowa. Podobna była postawa prymasa Stefana Wyszyńskiego, co widać w jego Zapiskach więziennych ${ }^{33}$. Cały czas okazywał królowi szacunek i wierność i nieustannie zapewniał o modlitwie za niego. Pragnął do końca pozostać wierny papieżowi i zachować jedność wiary katolickiej. Zachował spokój, mimo że toczyła się walka o jego życie wieczne i przyszłość Kościoła w Anglii. Uznał prawa potomstwa Anny Boleyn do sukcesji, ponieważ kwestia ta nie dotyczyła wiary. Podkreślał, że ustanawianie praw politycznych nie jest zadaniem Kościoła, a błąd w polityce nie jest równoznaczny $z$ herezją. Państwo nie może się mieszać do prawa kościelnego i dlatego oddał życie z rozkazu króla jako wierny jego sługa.

Po trzecie, panicznie bał się śmierci, jednak poczucie samotności i coraz większy lęk nie zaowocowały goryczą. Mimo że przytłaczała go świadomość własnej słabości, wszystko oddawał w ręce Boga. Więcej bólu sprawiała mu udręka duchowa, niepewność siebie niż sama myśl o cierpieniach fizycznych. Ważna dla niego była przyjaźń.

\footnotetext{
${ }^{33}$ Por. S. Wyszyński, Zapiski więzienne, Warszawa-Ząbki 2001.
} 
Po czwarte, T. More zachował wolność od odpowiedzialności za sumienia i decyzje innych. Nie osądzał swoich bliskich ani nikogo innego. Nie chciał komukolwiek narzucać swoich poglądów. Zostawił każdemu prawo do swobodnego formowania sumienia, ale żądał, aby i jemu pozwolono postapić zgodnie z własnym. Był więźniem sumienia i złożył swoje życie w imię wierności Kościołowi i Stolicy Apostolskiej.

Tuż przed wykonaniem wyroku 6 lipca 1535 roku, wstępując na szafot, powiedział: „Kiedy obejmowałem urząd kanclerza, prosiłeś mnie królu, bym wpierw słuchał Boga, a potem Ciebie, a dziś ginę za to, że wpierw słuchałem Boga, a potem Ciebie [...]"34. Można więc bez cienia wątpliwości stwierdzić, że u T. More’a zwyciężyły prawość i wierność własnemu sumieniu, ukształtowanemu według Bożego Prawa.

\section{The Defense of the Conscience Decision Made by Thomas More in the Face of Imprisonment and Death}

\section{Summary}

The article analyses Thomas More's firm attitude defending his conscience, which did not allow him to swear an oath. The basis for reflection is his prison correspondence, especially with her daughter Margaret. He remained faithful to his conscience because he refused to submit the required signatures and was beheaded, but gained eternal salvation. He studied for a long time, meditated and prayed to make the right decision. The closest urged him to change his decision, but he refused. He was not affected by accusations, slander, threats or flattery. He did not swear an oath and did not explain anything. He preserved freedom of conscience and responsibility for his own decisions. He did not judge anyone else. All the time he showed respect and loyalty to the king and constantly assured of his prayers in king's intentions. Despite the weakness and fear of death, he put everything into God's hands. He was a prisoner of conscience and gave his live in the name of fidelity to the Church and the Holy See.

\section{Keywords}

Thomas More, conscience, King Henry VIII, the Church, the spiritual battle, defending the faith

\section{Słowa kluczowe}

Tomasz More, sumienie, król Henryk VIII, Kościół, duchowa walka, obrona wiary

\section{Bibliografia}

Ackroyd P., The Life of Thomas More, New York 1999.

Cummings B., Conscience and the law in Thomas More, „Renaissance Studies” 23(2009), s. $463-485$.

\footnotetext{
${ }^{34}$ Por. J. Monti, The King's Good Servant But God's First, dz. cyt., s. 446-448.
} 
Harpsfield N., The Life and Death of Sir Thomas More, London 1931.

Logan G., The Cambridge Companion to Thomas More, Cambridge 2011.

Marius R., Thomas More, Harvard 1999.

Monti J., The King's Good Servant But God's First, San Francisco 1997.

More T., Pisma więzienne, tłum. W. Giertych, Poznań 1985.

Sargent D., Thomas More, Montana 2003.

Smith S., Interrogating Thomas More: The Conundrums of Conscience, „University of St. Thomas Law Journal" 1(2003), s. 592-613.

The Act of Supremacy, 1534, w: Documents of the English Reformation, ed. G. Bray, Cambridge 2004, s. 113-114.

The First Act of Succession (1534), w: Select Documents of English Constitutional History, eds. G. Adams, H. Stephens, New York 1914, s. 235-238.

The Last Letters of Thomas More, ed. A. de Silva, Michigan 2001.

Wegemer G., Thomas More: A Portrait of Courage, New York 1997.

Wood J., Sir Thomas More: A Man for One Season, w: The Broken Estate: Essays on Literature and Belief, New York 2000, s. 24-27. 